\title{
Divertículo uretral femenino
}

García Rodríguez J, González Huergo F*, García-Sastre García ME*, Regadera Sejas J.

Servicio de Urología I. Hospital Universitario Central de Asturias. Oviedo. *Servicio de Urología. Hospital Comarcal de Jarrio. Coaña. Asturias.

Actas Urol Esp. 2007;31(4):428

$\mathrm{S}_{\mathrm{s}}^{\mathrm{c}}$ trata de una mujer de 63 años que consula por infecciones urinarias de repetición, goteo terminal y masa en pared vaginal anterior. A la exploración se objetiva drenaje purulento por uretra a la presión de bultoma vaginal. Se realiza cistouretrografía (Fig. 1) objetivando divertículo uretral, confirmando drenaje uretral mediante uretroscopia.

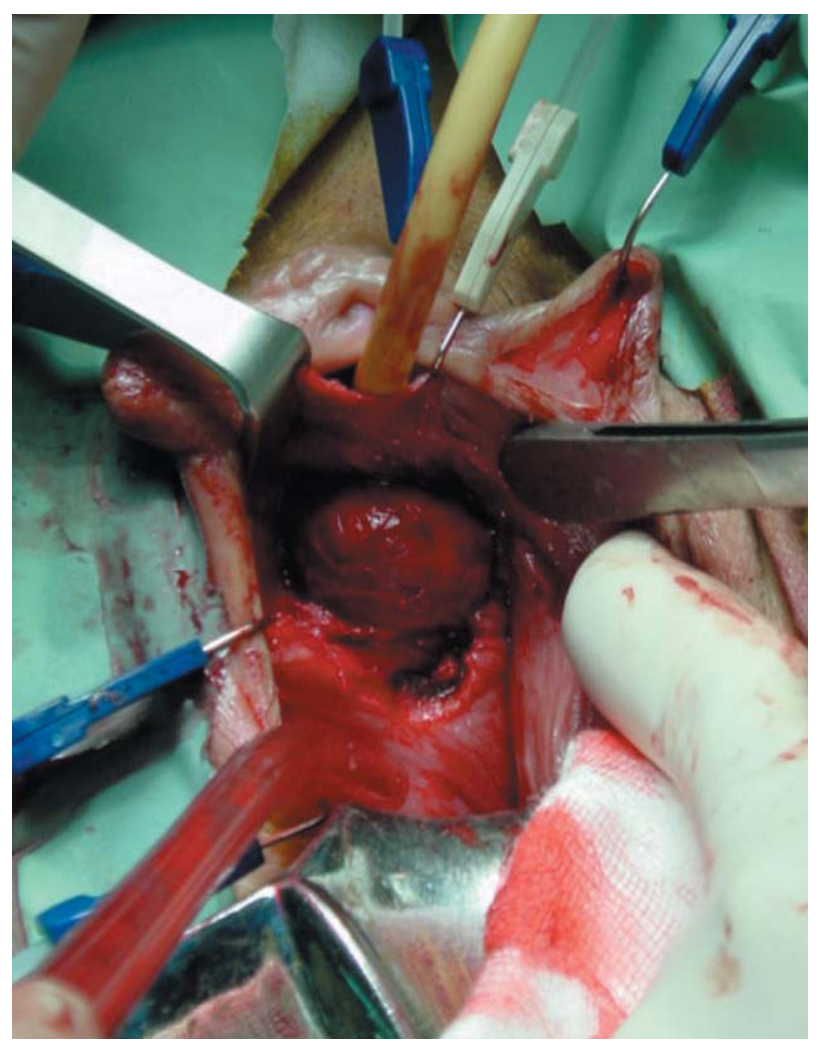

FIGURA 1

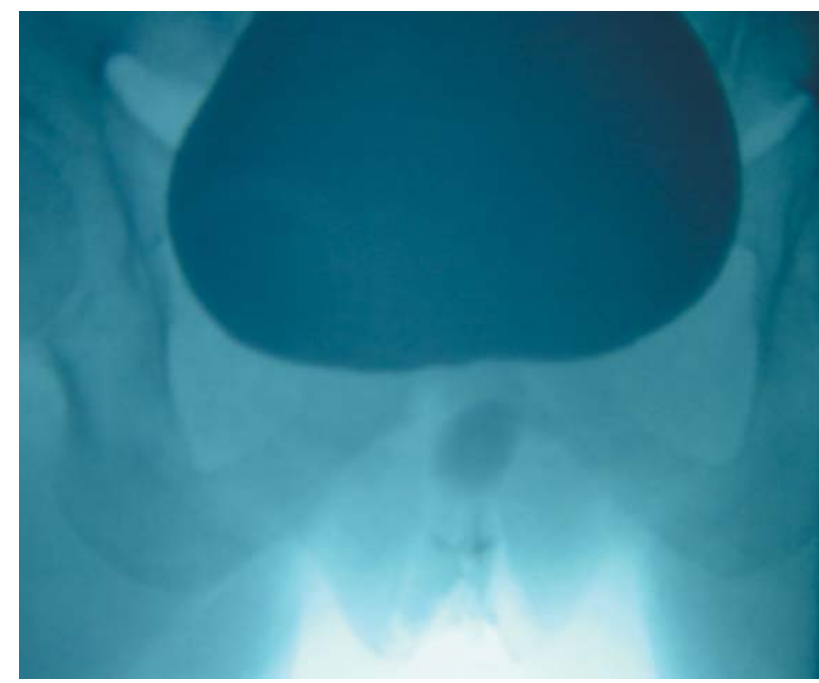

FIGURA 2

Se practica tratamiento quirúrgico mediante técnica de escisión transvaginal con liberación de las paredes del divertículo hasta el cuello del saco diverticular, cierre del mismo y realización de colgajo de pared vaginal sin superposición de suturas (Fig. 2).

En los controles posteriores se objetiva desaparición de clínica previa.

Correspondencia autor: Dr. J. García Rodríguez

Servicio de Urología I. Hospital Universitario Central de Asturias.

Celestino Villamil, s/n. 33006 Oviedo. Asturias

Tel.: 985108004

E-mail autor: jgrmed@hotmail.com

Información artículo: Imágenes en Urología

Trabajo recibido: marzo 2006

Trabajo aceptado: abril 2006 